\title{
Detecting thin layer by the use of different seismic geophones and special processing technique at an archaeological site in southeastern China
}

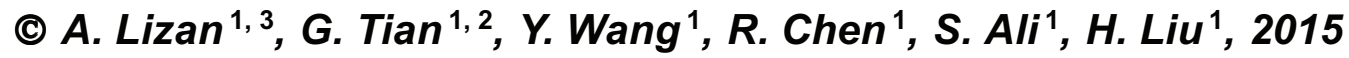 \\ ${ }^{1}$ Department of Earth Science, Zhejiang University, Hangzhou, China \\ ${ }^{2}$ Academy of Cultural Heritage, Zhejiang University, Hangzhou, China \\ ${ }^{3}$ Department of Basic Science, Sulaimani University, Sulaimani, Iraq
}

Received 23 July 2015

Presented by Editorial Board Member V. N. Pylypenko

\begin{abstract}
Властивості геофонів є важливими фракторами під час сейсмічних дослідженнях і суттєво впливають на якість даних. Розглянуто проблему отримання та обробки сейсмічних даних для екстремально неглибоких об'єктів. Оцінено застосовність різних сейсмічних геофонів і методик обробки для виявлення тонкого ґрунтового шару потужністю близько 20 см на глибині близько 2 м на археологічному об'єкті Лянгжу у Південно-Східному Китаї. Наведено сейсмічні дані, які отримано із застосуванням двох типів геофонів: нормальних з різними природними частотами, вставлених у ґрунт; таких, що буксуються на тросі і контактують із земною поверхнею. Комбінація частотних переваг двох різних типів геофонів має розширити ефективну ширину смуги частот отриманих даних. Розроблено метод часткового узгодженого фрільтрування частот під час обробки даних, що дає змогу поліпшувати розділення сейсмічних відображених даних. Показано, що для виявлення тонкого шару узгоджене фільтрування $€$ ефективнішим порівняно з бурінням та застосуванням інших геофізичних методів.

Ключові слова: тонкий шар, сейсмічні геофони, кабельні геофони, часткове узгоджене фільтрування.
\end{abstract}

Introduction. Geophysical methods are very useful for archaeological exploration because they are efficient and noninvasive compared to traditional excavation and can provide many details of subsurface features. The methods, which people generally choose to carry out archaeological surveys include electrical resistivity tomography (ERT) [Leucci, Greco, 2012], ground penetrating radar (GPR) [Conyers, 2004] and shallow seismology [Mahfooz et al., 2008]. Among these methods, ERT and GPR are most commonly applied because they are suitable to provide visible information efficiently at different depths, while seismic method is not widely used due to relatively low data acquisition efficiency and lack of resolution compared to others. Many scholars have implemented some seismic tomographic technique to locate buried structures and tumuli [Forte, Pipan, 2008] which only extracts the first arrival of all collected data. The seismic refraction has also been used to locate tumuli [Tsokas et al., 1995], to obtain background velocity and depth model [Benjumea et al., 2001]. However; available examples of seismic reflection use for archaeological study were mainly focused on the deeper part (more than $10 \mathrm{~m}$ ), practically due to strong scattering and surface wave promoted by shallow surface. In this study we will focus our interest on the problems of ultra-shallow seismic acquisition and processing by use of different geophones and a special match filtering method. High-resolution seismic exploration does not mean high-frequency exploration, if the natural frequency of a geophone is too high; not only the low frequency is reduced, but also the effective frequency band will fall into the non lineararea, producing nonlinear distortion and lowering resolution [Li et al., 2009]. 
A method of compensating conventional data with special coupling equipment was efficiently used to solve the bad-coupling problem in desert areas [Shi et al., 2005; Tian et al., 2006]. The authors of the article [Shen et al., 2012] has combined the advantages of the piezoelectric geophone by use of match filter, which efficiently broadened the bandwidth of the conventional data. In the next article [Shen et al., 2013] a case of study is presented by applying match filtering method that utilizes the high frequency components of high-sensitivity geophone data to compensate for conventional geophone data.

In this research, we have tried to evaluate the applicability of seismic method to detect a thin buried soil layer under $2 \mathrm{~m}$ depth. We collected data applying two kinds of geophones: normal geophones with natural frequencies of 60 and $100 \mathrm{~Hz}$ and towed cable geophones which can receive signal frequency up to several hundred $\mathrm{Hz}$. We applied a partial frequency match filtering method, which has improved the bandwidth frequency by focusing the data from above geophones in data processing, and achieved results showing the existence of the target layer.

The study area and previous geophysical work. The study area, called Liangzhu archaeology site, is located at north of Hangzhou city, Zhejiang Province, southeast China (Fig. 1). Historically it was a stretch of an ocean bay, which gradually piled up towards a large stretch of fertile plain. It is famous for Neolithic jade culture, and represents one of the earliest Chinese settlements, where the Liangzhu Culture flourished, the richest and most vivid civilization in China.

The Liangzhu Culture developed about 54004300 years ago, but suddenly disappeared from the Taihu Lake area about 4200 years ago when it reached its peak. In 1930 s the archaeologists dis- covered the first evidences of prehistoric culture and many jade, silk, ivory and pottery objects at Liangzhu. The first archaeological excavation was performed by Xingeng Shi in 1936 [Shi, 1938]. The successive excavations proved that such culture had advanced handicraft and agricultural skills, including jade and pottery processing, irrigation, paddy rice cultivation and aquaculture. Moreover, rammed earth remains of the ancient city wall, 40 to $60 \mathrm{~m}$ length, were discovered at the Liangzhu site in 2007. The total area of the ancient city was $2,900,000 \mathrm{~m}^{2}$, and the site was considered as the center of the $\mathrm{Li}-$ angzhu culture.

The study area is located at southeastern side of Mojiaoshan in the center of ancient Liangzhu city, an artificial rammed earth platform, in which that has been recognized as possible remains of prehistoric buildings and palace [Zhao, 2001]. The dimension of the platform is about 670 and $450 \mathrm{~m}$ in $\mathrm{E}-\mathrm{W}$ and $\mathrm{N}-\mathrm{S}$ directions respectively. It is partially covered by cultural layers of different periods, mainly including modern agricultural soil and sandy soil of the Han Dynasty (about 2000 years ago). A peach orchard presently covers the area. The thickness of the Neolithic rammed earth layer is about $10 \mathrm{~m}$ and a burnt soil layer with mixed ash and charcoal powder has just been found in the study area, buried $2 \mathrm{~m}$ more or less below the surface. The possible origin of the layer could be an ancient fire disaster or worship activities, but it is not clear yet.

Previous GPR studies provided a limited amount of useful information about the buried prehistoric cultural heritage of the Liangzhu Site, due to the effect of water saturated clay-rich soils. Experiments performed with different antennas hardly imaged a two meter deep layer of stones, with average thickness about $20 \mathrm{~cm}$.

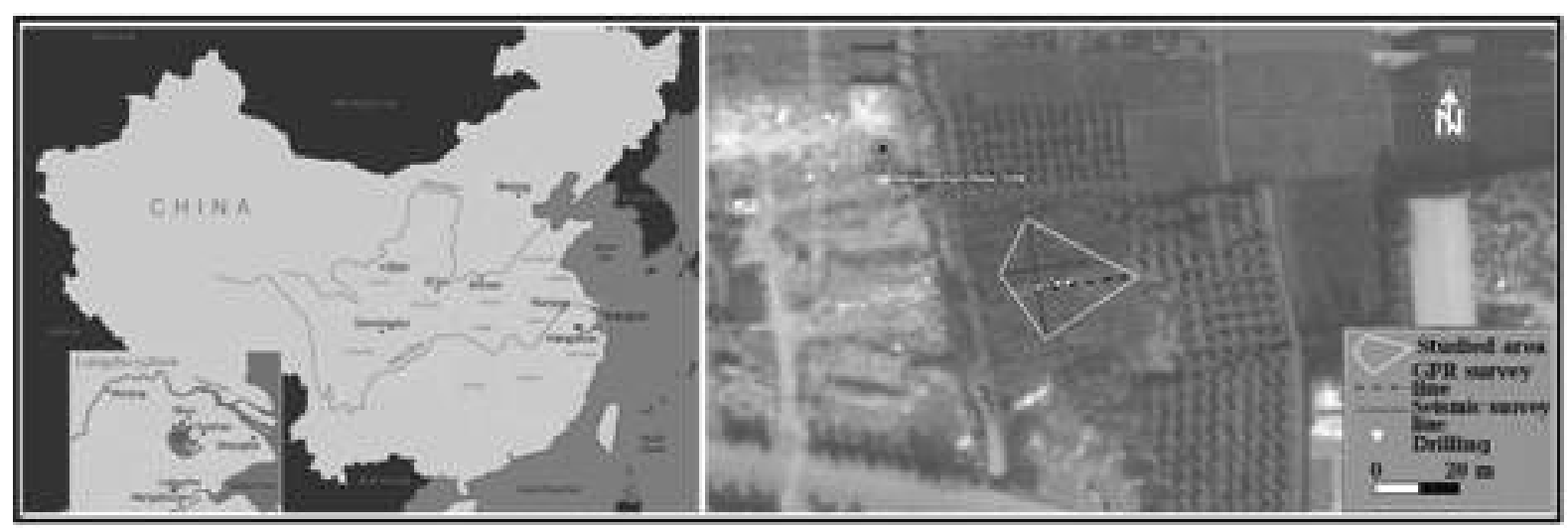

Fig. 1. A map of Liangzhu archaeology site location. 
Data acquisition. In this study we collected the data with two kinds of geophones. One is the normal geophone with natural frequency of 60 and $100 \mathrm{~Hz}$, the other one is towed cable geophone with frequency bandwidth of $20 \mathrm{~Hz}$ to $16 \mathrm{KHz}, 24$ channels, $50 \mathrm{~m}$ cable length, water proofed above $15 \mathrm{~m}$ and pulled away along the survey line.
Normal geophones should be inserted into the ground (Fig. 2, a) and connected to the seismic cable by hand, while the cable geophones are working as a set on the earth surface. Every geophone on the cable is pressed by a small yellow bag filled with soil or sand (Fig. 2, b) to be coupled to the surface. We applied a 24-channel seismograph (Fig. 2, b)

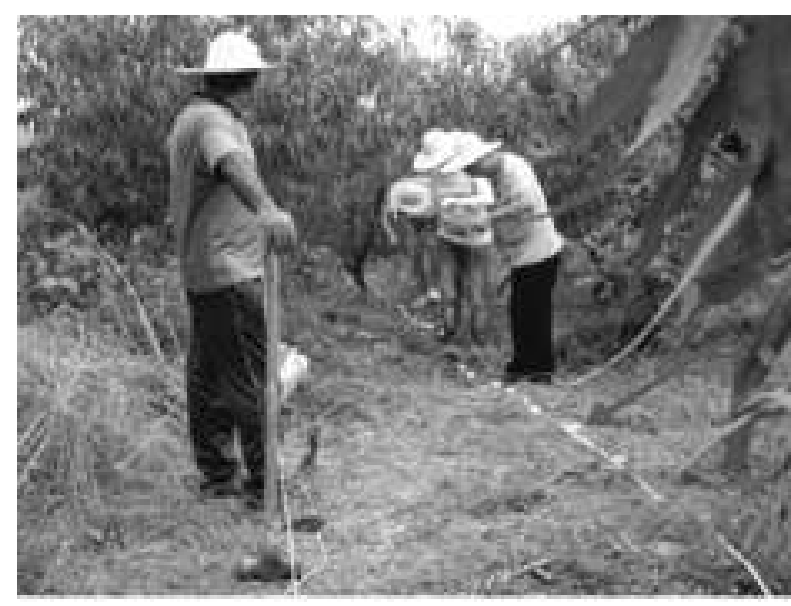

a

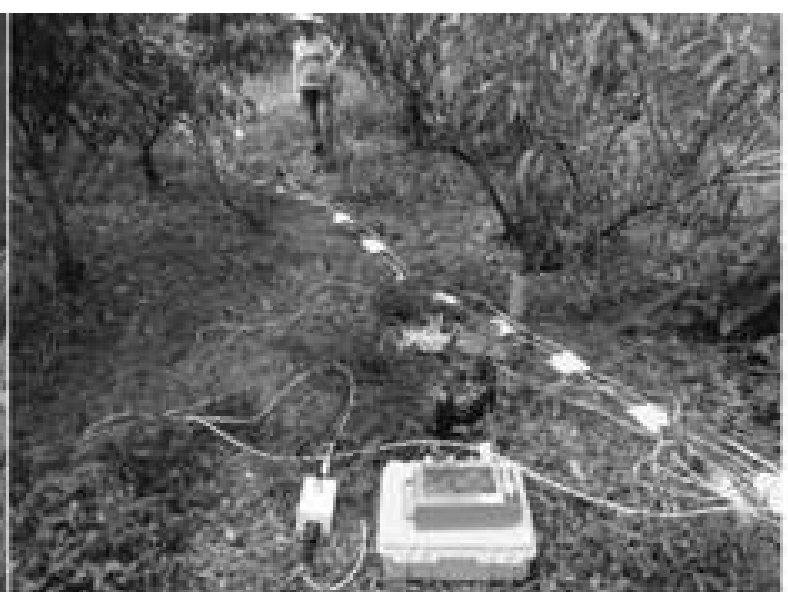

$b$

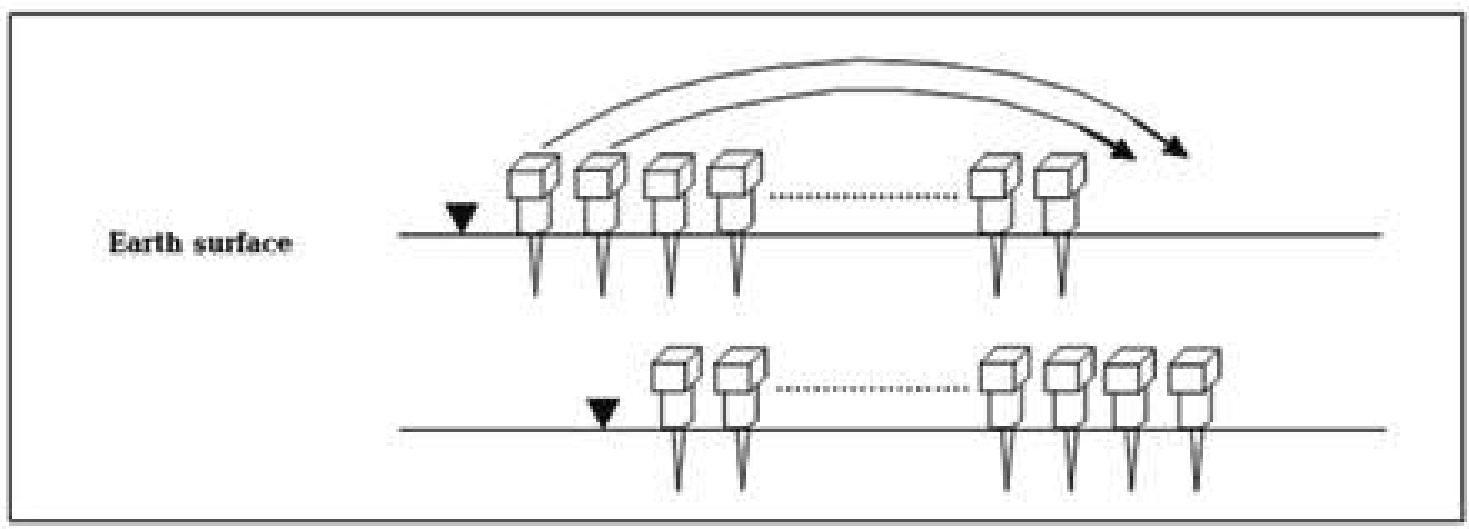

c

Earth surface

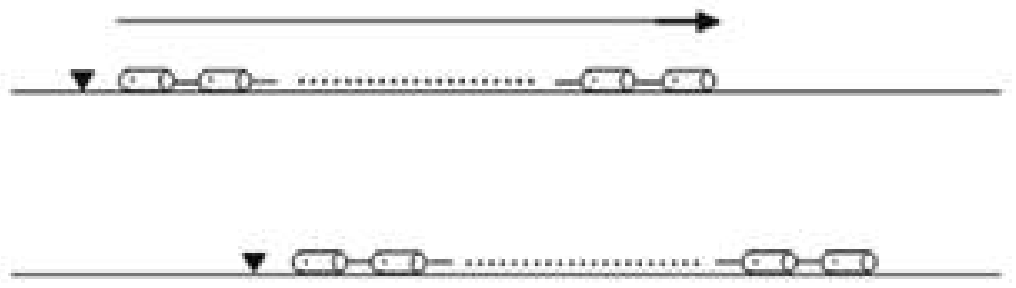

$d$

Fig. 2. Field work of normal geophones (a), field work of cable geophones (b), data acquisition by normal geophones $(c)$, data acquisition by cable geophones $(d)$. 
connected to a hammer source (Fig. 2, a), and accomplished line data acquisition in the way of CDP reflection survey. Because the research target is a thin layer spreading horizontally in the study area; we chose geophone spacing and offset both in $0,5 \mathrm{~m}$, and the shot spacing was $1 \mathrm{~m}$.

For normal geophones, when we move to the next shot, we have to take the first two geophones to the end (Fig. 2, c), and reconnect them with the seismic cable. However, for cable geophones, we only need to drag the cable forward and the whole array will move together (Fig. 2, d), which takes much less time and physical manpower.

Data processing. After data acquisition, we ap-plied the following processing flow on seismic raw records:

- data editing,

- trace equalization,

- frequency analysis,

- time gain,

- fK filtering,

- velocity analysis,

- NMO,

- stacking.

The natural frequency of any geophone is the lower limit of recording bandwidth in the geophone transfer function. Therefore use of geophones of different natural frequencies can only change the low cut signal frequency for $60 \mathrm{~Hz}, 100 \mathrm{~Hz}$ and cable geophones. It was also found that each geophone has advantage on typical period of frequency (Fig. $3, a)$. Although the amplitude of cable geophone is much smaller than of normal geophones, we think frequency bandwidth has an important effect on resolution. We have noted that the frequency of the cable geophones from 100 to $300 \mathrm{~Hz}$ are not good as of normal geophones; so we designed a partial frequency match filter to combine the advantages of these geophones in frequencies. Thus we will obtain a seismic wave form with a broader frequency bandwidth and higher resolution as shown in Fig. $3, b$. We choose the relative amplitude as a parameter and set the match filter for cable geophone as in Equation (1).

We get the ideal output $y(t)$ from the following method:

$Y(f)= \begin{cases}X_{1}(f) & X_{1}(f)>X_{2}(f) \& X_{1}(f)>X_{3}(f), \\ X_{2}(f) & X_{2}(f)>X_{1}(f) \& X_{2}(f)>X_{3}(f), \\ X_{3}(f) & X_{3}(f)>X_{1}(f) \& X_{3}(f)>X_{2}(f) .\end{cases}$

Where $Y(f), X_{1}(f), X_{2}(f), X_{3}(f)$ are the FFT of $y(t), x_{1}(t), x_{2}(t), x_{3}(t)$, and $x_{1}(t)$, $x_{2}(t), x_{3}(t)$ are partial frequency match filter operator. Then the match filter is designed as follows:

$$
y(t)=x_{3}(t) * f(t) .
$$

Then we get

$$
F(f)=Y(f) / X_{3}(f) .
$$

According to Equation (1), we get

$$
F(f)=\left\{\begin{array}{l}
X_{1}(f) / X_{3}(f) \\
X_{2}(f) / X_{3}(f) . \\
1
\end{array}\right.
$$

Where $X_{1}(f)$ and $X_{2}(f)$ are complex quantities. Since we only want to make complement on amplitude, we take the modulus of $F(f)$ :
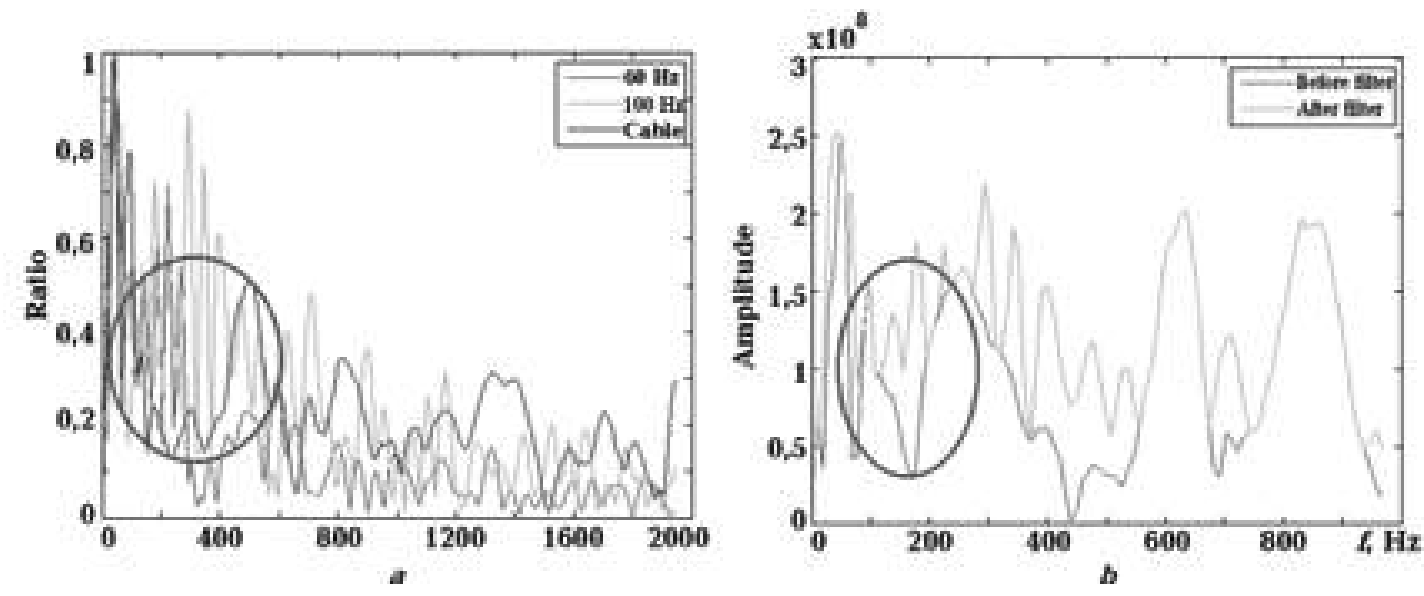

Fig. 3. Relative amplitude spectra: a - of $60 \mathrm{~Hz}, 100 \mathrm{~Hz}$ and cable geophones, $b$ - before and after filtering for cable. 


$$
F_{r}(f)=|F(f)| \text {. }
$$

Then we apply the filter to the raw records, and going through the same data processing flow described above for comparison.

Results. The following Fig. 4 demonstrates the stack profiles for $60 \mathrm{~Hz}, 100 \mathrm{~Hz}$ geophones and cable geophones respectively. We can observe that there are mainly two layers which are marked blue and red in all profiles, the red one is representing the thin bed which is our target layer while the blue one is representing the bottom of the artificial hill.

In Fig. 4, a the stack profile for $60 \mathrm{~Hz}$ geophones shows the thin layer more clearly than other even cable geophones, after applying the filter, resolution of the thin layer is not good, comparing with the cable geophones. As for the stack profile of $100 \mathrm{~Hz}$ geophone in Fig. 4, c, a bottom layer could not be seen clearly due to lack of penetrating energy, as well as after applying the filter (Fig. 4, d).

Although the response of $100 \mathrm{~Hz}$ geophones has some high frequency components than others; there were lacks of flat and wide bandwidth frequencies, whereas those of the cable geophone were clearer.

Fig. $4, f$ shows improvement of the resolution after applying match filtering for cable geophones and shows more details in the first $20 \mathrm{~ms}$ period, we can get more information about the thin bed.

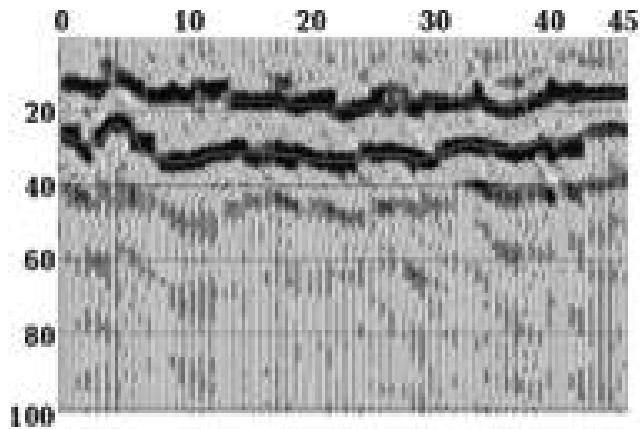

a
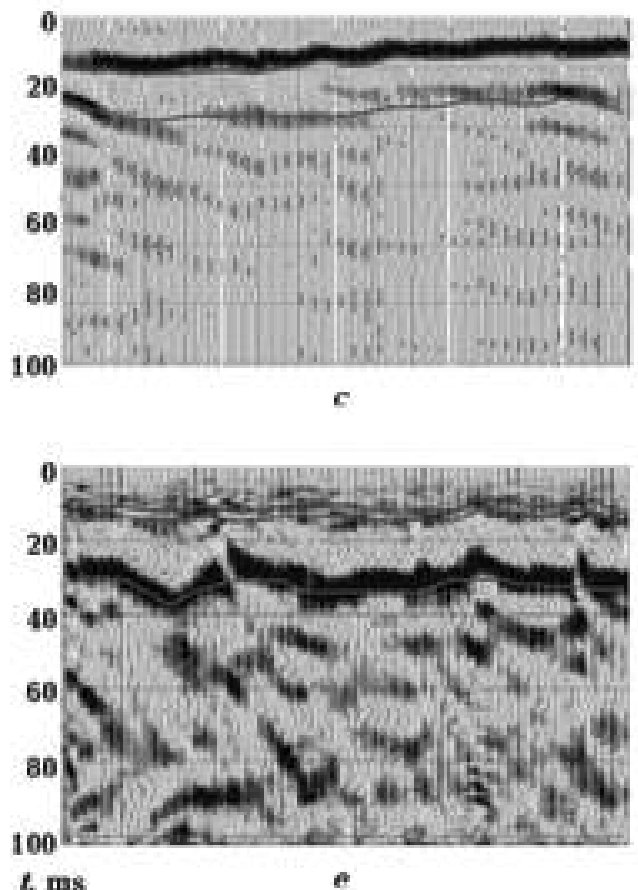

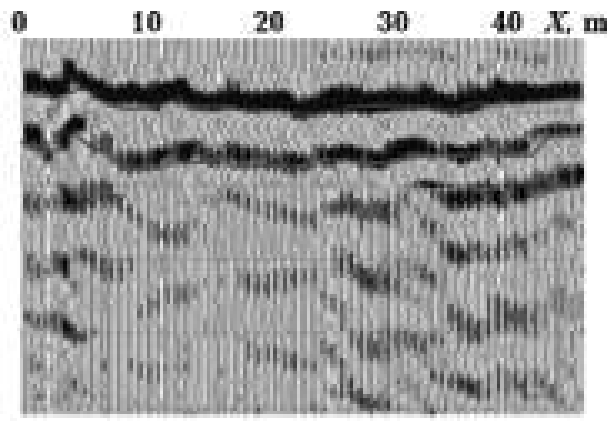

b

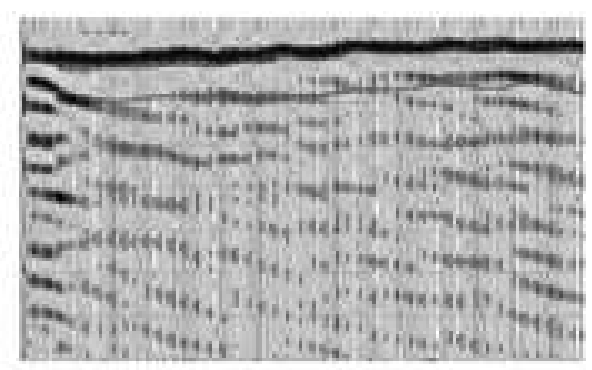

d

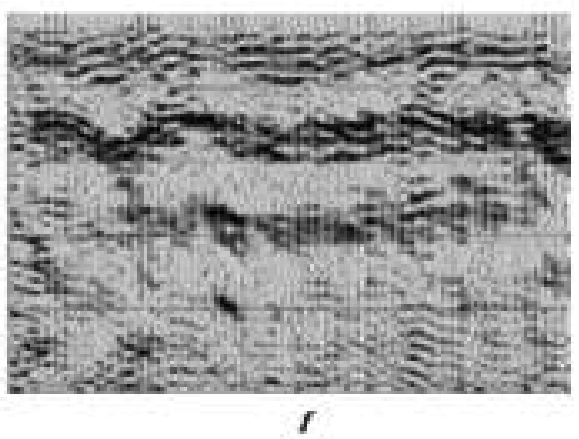

Fig. 4. Stack profiles from: $a-$ raw data of $60 \mathrm{~Hz}$ geophone for line $2 ; b-60 \mathrm{~Hz}$ geophone after match filtering for line 2; $c$ - raw data of $100 \mathrm{~Hz}$ geophone for line $1 ; d-100 \mathrm{~Hz}$ geophone after match filtering for line 1 ; e - raw data of cable geophone for line $2 ; f-$ cable geophone after match filtering for line 2 . 
Fig. 5 is the amplitude spectrum of Fig. 4. There are some higher frequencies components existed from $100 \mathrm{~Hz}$ up to $300 \mathrm{~Hz}$ which construct a base
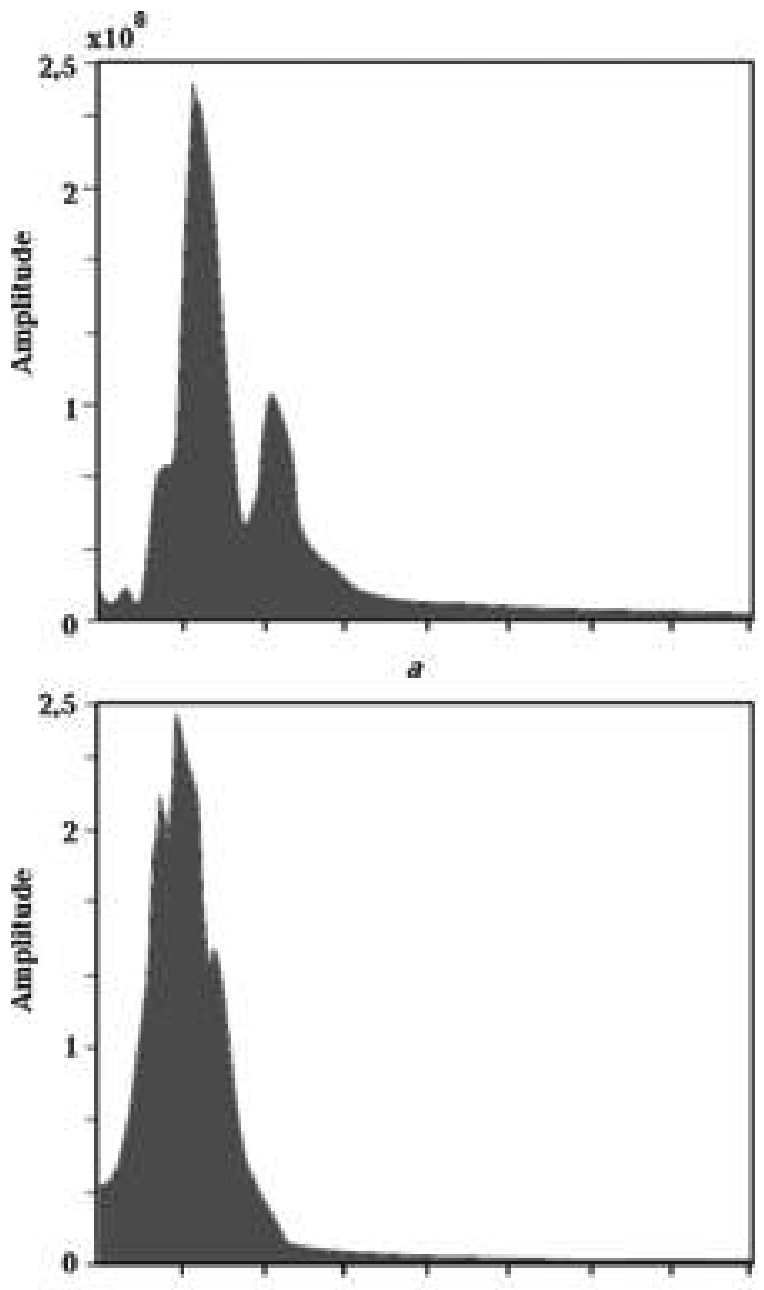

$c$

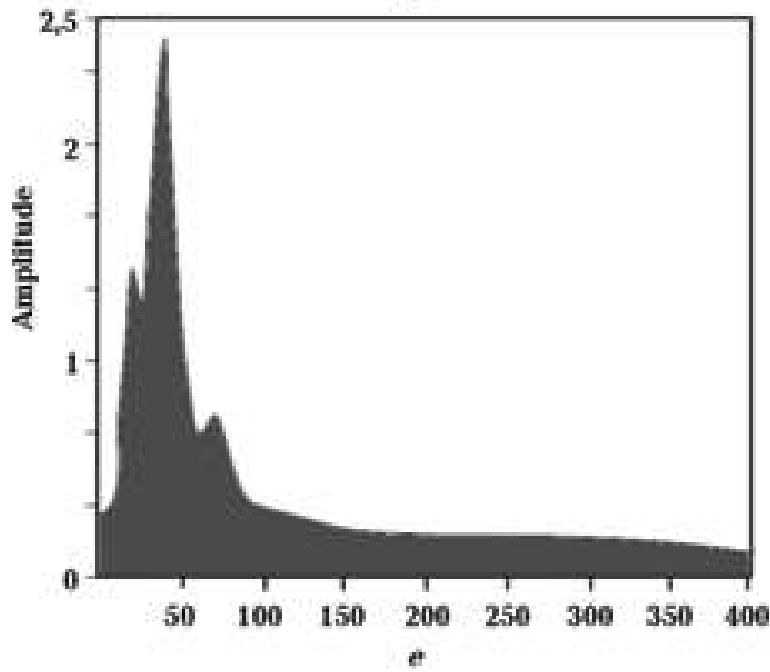

for applying the filter. Much higher and bigger frequency components were presented in Fig. $4, f$ by the cable geophones, the band width of frequency
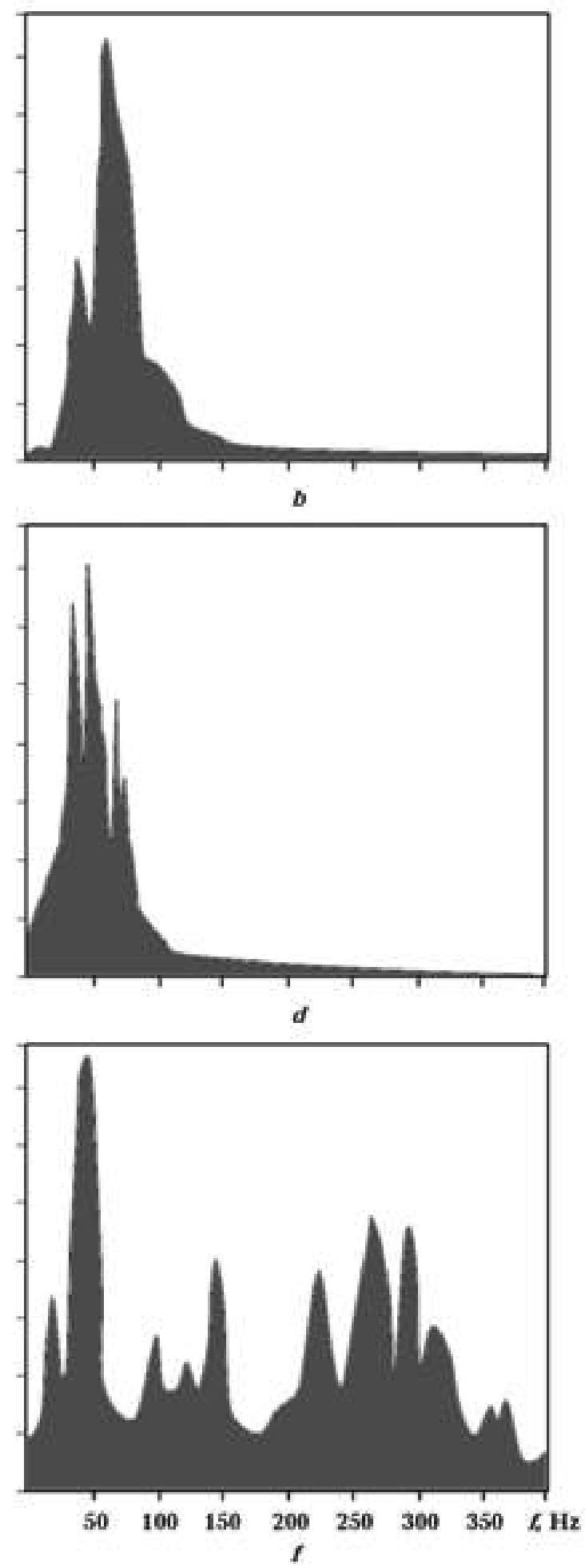

Fig. 5. Relative amplitude spectrum from: $a$ - raw data of $60 \mathrm{~Hz}$ geophone for line $2 ; b-60 \mathrm{~Hz}$ geophone after match filtering for line 2; c - raw data of $100 \mathrm{~Hz}$ geophone for line 1; $d-100 \mathrm{~Hz}$ geophone after match filtering for line 1; e — raw data of cable geophone for line 2; $f$ - cable geophone after match filtering for line 2. 
reach to about $380 \mathrm{~Hz}$ after applied partial match filter as shown in Fig. 5, e. This broader range is the reason why the normal geophones did not perform well due to limitation in bandwidth; it loses high-frequency data. The peak frequency recorded by the normal and cable geophone method was approximately $50-60 \mathrm{~Hz}$ as shown in Fig. 5. The bandwidth frequency of cable geophone was broader than the bandwidth frequency of the normal geophone, therefore we get more accurate figure of the subsurface with the cable geophone obviously after applying the partial frequency mach filter as shown in Fig. 4, e.

The generally accepted threshold for vertical resolution of a layer is a quarter of the dominant wavelength. A layer is called an ultra-thin layer when, $\lambda / d>4$ [Widess, 1973], where $\lambda$ is the dominant wavelength within the layer and $d$ is the layer thickness. The maximum requency of the amplitude spectrum in Fig. $5, e$ is about $385 \mathrm{~Hz}$ which defined the tuning thickness. The seismic frequency band increases, the tuning thickness will decrease in our case as the velocity of the thin layer is about $350 \mathrm{~m} / \mathrm{s}$, and the thickness of the bed is about $20 \mathrm{~cm}$ that just satisfies the criterion for the resolution of a thin bed.

Moreover; we have done some drilling work as reference to our seismic result, by the use of our tra- ditional Luoyang Spade, a very popular tool for archaeological exploration in China. The study area is on top of an artificial hill, making the water level deeper, we were able to drill 2,4 m going through the thin layer as shown in Fig. 6, we choose the place of drilling on the point that crosses our seismic survey line with the attribute technique of GPR survey line by Zhao [Zhao et al., 2015], to be used for comparing our result with GPR results as shown in Fig. 7.

We measured the ultrasonic wave velocity of the core samples in the field soon after the drilling, to limit variations of moisture content and to ensure the reliability of the measured value with a machine dividing the radius of the spade $(2,5 \mathrm{~cm})$ by wave passing time as shown in Table.

From stacking profile we cannot see A and B layers because actually no significant differences of acoustic impedances between A and B, whereas layer $\mathrm{D}$ has much contrast between $\mathrm{C}$ and $\mathrm{D}$, and between $\mathrm{D}$ and $\mathrm{E}$. The reflection from the boundary between $\mathrm{B}$ and $\mathrm{C}$ is coincident with the direct waves in time which were muted unfortunately.

According to [Zhao et al., 2015], they calculated the instantaneous phase of the GPR data obtained with different configurations to focus on the buried layer and enhance the performance in tar-

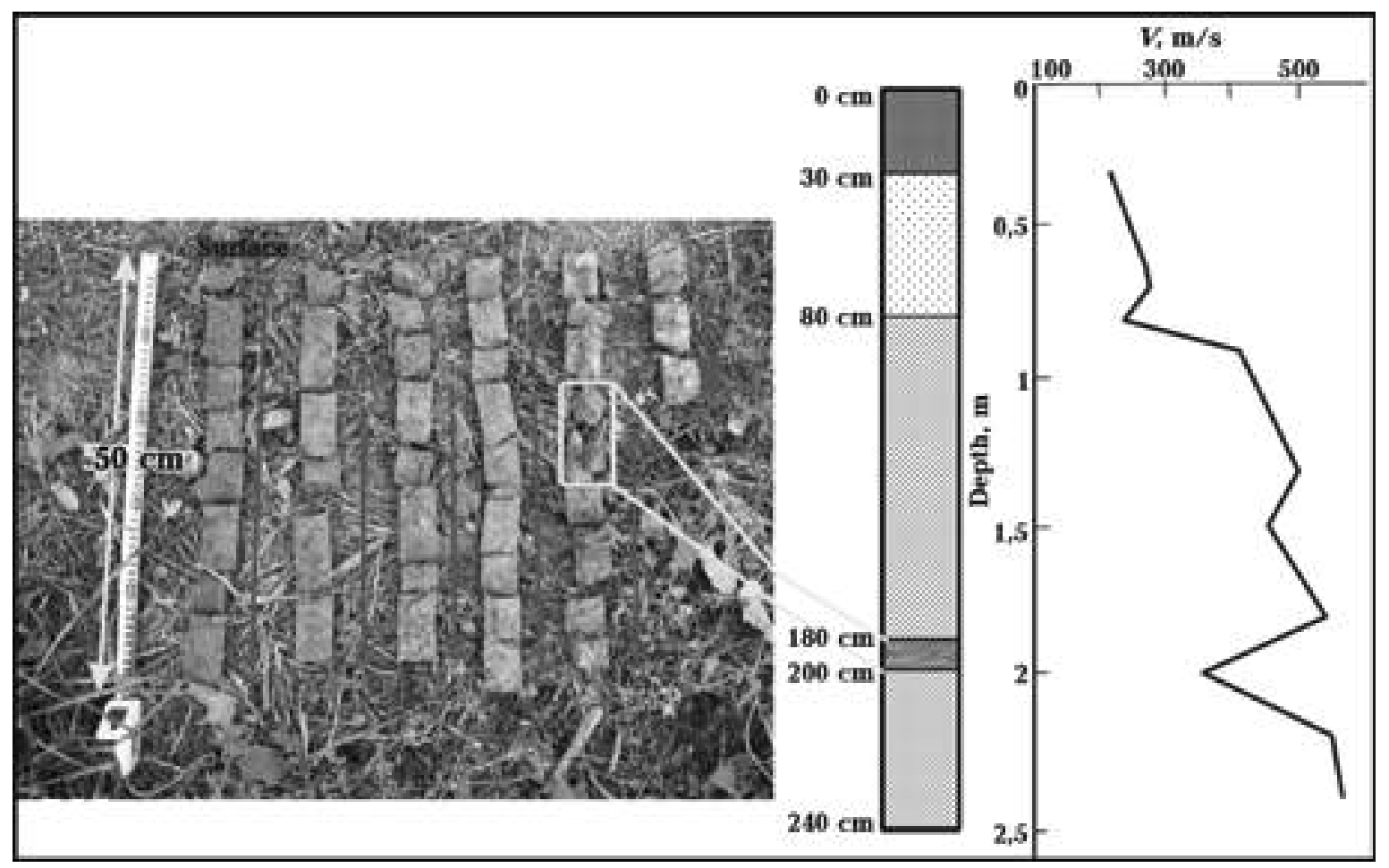

Fig. 6.Velocity measurements based on drilling results. 


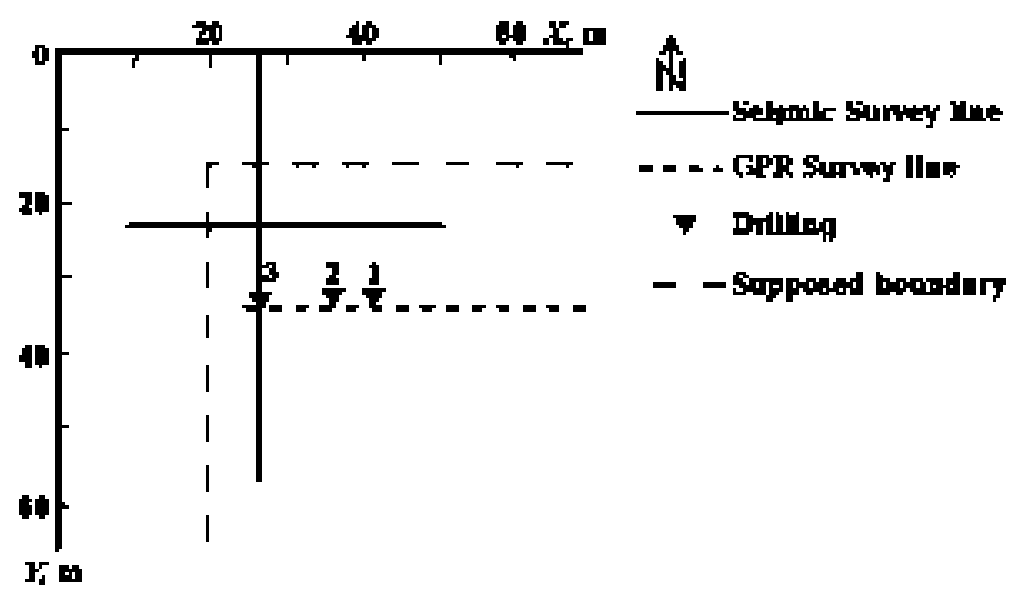

Fig. 7. Location map of seismic and GPR survey lines.

Wave velocity measured on soil samples of drill 3

\begin{tabular}{|c|c|c|c|}
\hline Layer & Depth, cm & Time, us & $\begin{array}{c}\text { Velocity, } \\
\mathrm{m} / \mathrm{s}\end{array}$ \\
\hline A & $20-30$ & 115 & 217 \\
\hline B & $30-60$ & 95 & 263 \\
\hline & $60-70$ & 92 & 270 \\
\hline & $70-80$ & 106 & 236 \\
\hline C & $80-100$ & 60 & 417 \\
\hline & $100-130$ & 50 & 500 \\
\hline & $130-150$ & 55 & 455 \\
\hline D & $150-180$ & 46 & 543 \\
\hline E & $200-220$ & 46 & 357 \\
\hline & $220-240$ & 45 & 556 \\
\hline
\end{tabular}

get detection. The use of the local standard deviations, based on the instantaneous phase attribute to make the interpretation easier and more constrained is shown in Fig. 8. Such geometrical attribute can improve the interpretation by emphasizing the continuity and discontinuity properties by enhancing the attainable resolution.

The present work demonstrates that a proper combination of data acquisition and processing analysis techniques for both GPR [Zhao et al., 2015] and seismic can overcome the limits of standard GPR and seismic techniques and successfully image low-contrast and thin cultural targets such as contacts between clayey soils and rammed sandy soils, which are subsurface conditions frequently met at prehistoric sites.

Conclusion. We tried different geophones and processing techniques to evaluate the effect of high resolution shallow seismic exploration applied to detect a thin soil layer at an archaeological site. The broader frequency bandwidth is one of the advantages of the use of cable geophones, which can obvi-

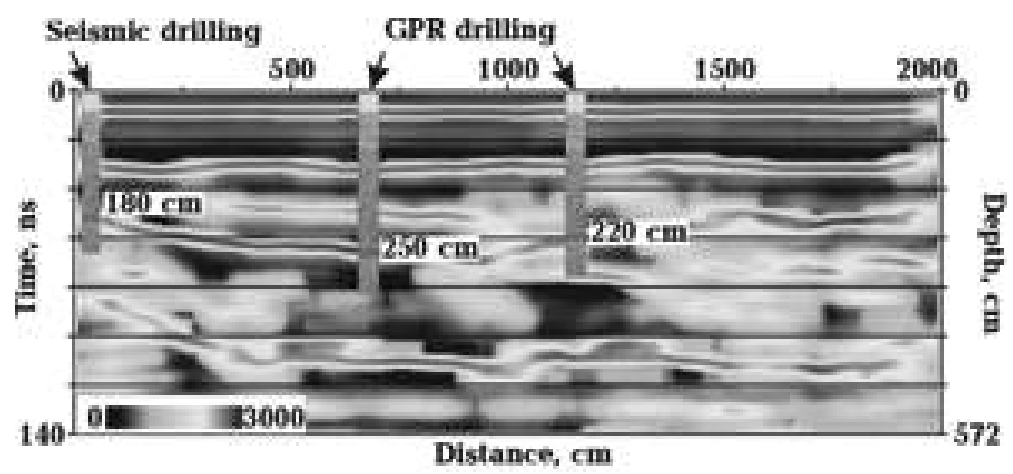

Fig. 8. GPR interpretation of the section reported correlated with drilling results (revised after [Zhao et al., 2015]). 
ously increase data acquisition efficiency, and also improves resolution espe-cially for the shallow part after apply-ing the partial frequency filter. The ap-plication of partial frequency match filtering on the field data shows that this method sufficiently combines the advantages of different kind of geophones, effectively widens the bandwidth and improves the quality of the acquired seismic data. And also the cable geophone speeds up the acquisition system instead of planting geophones, connected to the ground, therefore this new technique can replace the normal geophone use.

\title{
Detecting thin layer by using different seismic geophones and special processing technique at an archaeological site in southeastern China
}

\author{
(C) A. Lizan, G. Tian, Y. Wang, R. Chen, S. Ali, H. Liu, 2015
}

The properties of geophones are important factors for high-resolution seismic exploration and have great influence on data quality. In this study we will address the problems of ultrashallow seismic data acquisition and processing. The purpose of our study is to evaluate the applicability of using different seismic geophones and processing techniques, to detect a thin soil layer about $20 \mathrm{~cm}$ in thickness under the depth of about $2 \mathrm{~m}$ in Liangzhu archaeological site, Southeastern China. We have collected seismic data with two kinds of geophones, normal geophones with different natural frequencies inserted into the ground, and towable cable geophones contacting the earth surface. We considered combining the frequency advantages of these two different kinds of geophones to broaden the effective bandwidth of the acquired data. To achieve this, we designed a partial frequency match filtering method in data processing which helps to improve the resolution of seismic reflected data. The result of stacking profiles shows that match filtering is effective in detecting a thin layer compared with drilling samples and other geophysical works.

Key words: thin layer; seismic geophones; cable geophones; partial frequency match filtering.

\section{References}

Benjumea B., Teixido T., Pena J. A., 2001. Application of the CMP refraction method to an archaeological study (Los Millares, Almeria, Spain). J. Appl. Geophys. 46 (1), 77-84.

Conyers L. B., 2004. Ground-penetrating radar for archaeology. Walnut Creek, California: Altamira Press, $203 \mathrm{p}$.

Forte E., Pipan M., 2008. Integrated seismic tomography and ground-penetrating radar (GPR) for the high-resolution study of burial mounds (tumuli). J. Archaeological Sci. 35 (9), 2614-2623.

Leucci G., Greco F., 2012. 3D ERT Survey to Reconstruct Archaeological feature in the "Spirit Santo" Church Ruins at the Site of Occhiola' (Sicily, Italy). J. Archaeological Sci. 1 (1), 1-6.

Li G., Chen G., Zhong J., 2009. Analysis of geopho- ne properties effects for land seismic data. Appl. Geophys. 6 (1), 93-101.

Mahfooz A. H., Magdy A. A., Azza M. H., Motoyuki S., Thomas W., Abeer A. E., 2008. Shallow geophysical investigation at the Akhmim archaeological Site, Suhag, Egypt. Appl. Geophys. 5 (2), 136143.

Shen H. L., Tian G., Shi Z. J., 2013. Partial frequency band match filtering based on high sensitivity data: method and applications. Appl. Geophys. 10 (1), $15-24$.

Shen H. L., Tian G., Shi Z. J., Zhang X. T., Cong Z. G., Yan L. Z., 2012. Application of piezoelectric matched filtering technique in Tabamiao region. J. Zhejiang University (Engineering Science) 46 (3), 560567 (in Chinese). 
Shi X., 1938. Liangzhu - Preliminary report on pottery cultural site. Education of Zhejiang Province Press (in Chinese).

Shi Z. J., Tian G., Dong S. X., He H. Y., Wang Z. J., 2005. Match filtering of geophone coupling for high frequencies of seismic data in desert area. Geophys. Prospect. Petroleum 44 (3), 261-263 (in Chinese).

Tian G., Shi Z. J., Dong S. X., Wang Z. J., 2006. Geophone coupling match and attenuation compensation in near-seismic exploration. J. Environ. Eng. Geophys. 11 (2), 111-122.

Tsokas G. N., Papazachos C. B., Vafidis A., Lou- coyannakis M. Z., Vargemezis G., Tzimeas K., 1995. The detection monumental tombs buried in tumuli by seismic refraction. Geophysics 60 (6), 17351742.

Widess M. B., 1973. How thin is a thin bed. Geophysics $38(6), 1176-1180$.

Zhao W., Tian G., Forte E., Pipan M., Wang Y., Li X., Shi Z., Liu H., 2015. Advances in GPR data acquisition and analysis for archaeology. Geophys. J. Int. (in press).

Zhao Y., 2001. Excavation of the Mojiaoshan Site at Yuhang in 1992 and 1993. Cultural Relics 12, 4-19 (in Chinese). 